Kalem Eğitim ve İnsan Bilimleri Dergisi 2019, 9(1), 95-115, doi: 10.23863/kalem.2019.121

Makale Gönderim Tarihi:02.04.2018 Makale Kabûl Tarihi:10.06.2018

\title{
Effects of "Geography of the Turkic World" Course on Social Studies Teacher Candidates' Views about Turkic Culture and Turkic World ${ }^{1}$
}

\author{
Assoc. Prof. Dr. Meryem HAYIR-KANAT* \\ Yıldız Technical University, College of Education, Department of Social Sciences and Turkish Language \\ Education, İstanbul / Turkey, meryemhayir@hotmail.com, ORCID: 0000-0001-2345-6789

\section{Assist. Prof. Dr. Genç Osman İLHAN}

Yıldız Technical University, College of Education, Department of Social Sciences and Turkish Language Education, İstanbul / Turkey, gosman@yildiz.gov.tr, ORCID: 0000-0003-4091-4758

\begin{abstract}
The purpose of this study is to measure the expectations regarding the course on "Geography of the Turkic World", an elective course given in the Social Studies Education Departments of Education Faculties in Turkey, of the students who opt for it, and the extent to which the course met these expectations. The research was conducted in the faculty of education, department of social studies education from a University in İstanbul. Sample group of the study consists of 17 prospective teachers of social studies who had selected the course on Geography of the Turkic World. The study covering the 2015 spring term was conducted in a total period of 16 weeks. In the research, mixed method was used and concurrent/parallel design was utilized.
\end{abstract}

\footnotetext{
${ }^{1}$ A part of this study was presented in "International Turkish Education Sciences and Social Sciences" in Antalya between $1^{\text {st }}-4^{\text {th }}$ December 2016 as a verbal statement.

* Sorumlu Yazar. Tel: +90 5336433193

(C) 2019 Kalem Eğitim ve Sağlık Hizmetleri Vakfı. Bütün Hakları Saklıdır. ISSN: 2146-5606
} 
Quantitative and qualitative data was collected concurrently so as to consist variation among each other. In the qualitative dimension, data was collected through open ended questions, while in the quantitative dimension data was reached via pre-tests and post-tests. Collected data was analysed through content analysis in the qualitative dimension, and through $t$ test in the quantitative dimension. According to the results deduced from the data obtained from the study, it has been detected that perceptions of the students regarding the Turkic World changed positively, their knowledge and levels of interest increased, Turkic Culture had expanded to a greater area than they thought and that they realized many misconceptions they had.

Keywords: Change in perception; Course on geography of the Turkic World; Education; Turkic culture; Turkic world; Social studies education.

\section{Türk Dünyası Coğrafyası Dersinin Sosyal Bilgiler Öğretmen Adaylarının Türk Kültürüne ve Türk Dünyasına Bakış Açılarına Etkisi}

\section{$\ddot{\mathbf{O} z}$}

Bu araştırmada Türkiye'deki Eğitim Fakültelerinin Sosyal Bilgiler Eğitimi Bölümlerinde seçmeli ders olarak okutulan "Türk Dünyası Coğrafyası" dersini seçen öğretmen adaylarının beklentileri ve dersin bu beklentileri karşılama düzeyini ölçmek amaçlanmıştır. Araştırma İstanbul ilinde yer alan bir üniversitenin eğitim fakültesi sosyal bilgiler eğitimi anabilim dalında yapılmıştır. Çalışmanın örneklem grubunu Türk Dünyası Coğrafyası Dersi'ni seçen 17 sosyal bilgiler öğretmen adayı oluşturmuştur. 2015 Bahar dönemini kapsayan araştırma toplamda 16 haftalık bir süreçte gerçekleştirilmiştir. Karma yöntemin kullanıldığı araştırmada eşzamanlı/paralel desenden yararlanılmıştır. Nitel ve nicel veriler aynı zamanda toplanmış ve birbiriyle çeşitleme yapılması sağlanmıştır. Nitel boyutta açık uçlu sorulardan veri toplanırken nicel boyutta ön test ve son test yoluyla verilere ulaşılmıştır. Toplanan veriler nitel kısımda içerik analizi yoluyla analiz edilirken, nicel kısımda ise bağımlı $t$ testinden yararlanılmıştır. Çalışmadan ulaşılan sonuçlara göre ders sürecinde yapılan uygulamalarla öğretmen adaylarının Türk Dünyası'na yönelik algılarının olumlu yönde değiştiği, bilgilerinin ve ilgilerinin arttığı, düşündüklerinden daha büyük bir alana Türk Kültürü'nün yayılmış olduğu ve birçok yanlış öğrenmenin (yanılgının) farkına vardıkları belirlenmiştir.

Anahtar Kelimeler: Türk dünyası coğrafyası dersi; Türk dünyası; Türk kültürü; Sosyal bilgiler eğitimi; Öğretmen adayı. 


\section{Introduction}

There are different definitions in various sources regarding the boundaries of the Turkic World. "The area extending from Balkan Peninsula in the West, to the coasts of the Pacific Ocean in the East, and from the Arctic Ocean in the North, to Tibet in the South" (Yiğit, 2000) has been defined as the boundaries of the Turkic World, while it has also been defined as "the area extending from the Adriatic Sea to the Great Wall of China" (Doğanay, 1995; Özey, 2009). As being reference text for the course, Yiğit's book (Yiğit, 2000) was used as the primary source and thus it was assumed that this affected the formation of the students' perceptions about the Turkic World. Some researchers, on the other hand, recognize as the Turkic World the entire geography where Turks lived as independent states, autonomous republics and Turkic communities, thus the boundaries covered a much larger area. (Kalafat, 1994; Türkkahraman and Fidan, 2005). This area has also been deemed by many scholars as being a region of great strategic importance, therefore knowing about the Turkic World can also be a guide to understand what has happened in the world (Gündoğdu, 2009; Özey, 2009). Turks are one of the nations that won the fight for existence and have not lost their place in the world scene. When historical records are examined, we encounter the name Turk in Orkhon Inscriptions for the first time. The word Turk is mentioned in the inscriptions as "Türük" (Kafesoğlu, 2012, p.44). Different explanations come up in multiple sources about the meaning of the name Turk. The name Turk means strong-powerful, and according to Chinese sources it means "helmet" (Sezer, 2011).

It is beyond doubt that education and educational institutions play a crucial role in establishing cooperation between people living in these geographies. According to one research, in Turkey, on secondary school age, while the percentage of those who take courses for learning about the Turkic World is $55 \%$, the rate of those who wish to take such course proves to be $87 \%$ (Topbaş and Baran, 2010). We see that courses for learning about the Turkic World are superficial, as $81 \%$ stated that they had not taken a course to learn about the Turkic Culture. $87 \%$ of them stated that they would like to take such a course if offered. Therefore, it is important that this interest towards the Turkic World is addressed, and that during lecturing of this subject visual materials are opted for instead of memorization, and methods that enable student to learn the knowledge by constructing it are used. It was suggested by another research that our knowledge about the Turkic World, a 
subject of such great interest, is extremely insufficient and shallow (Topal and Sezer, 2016).

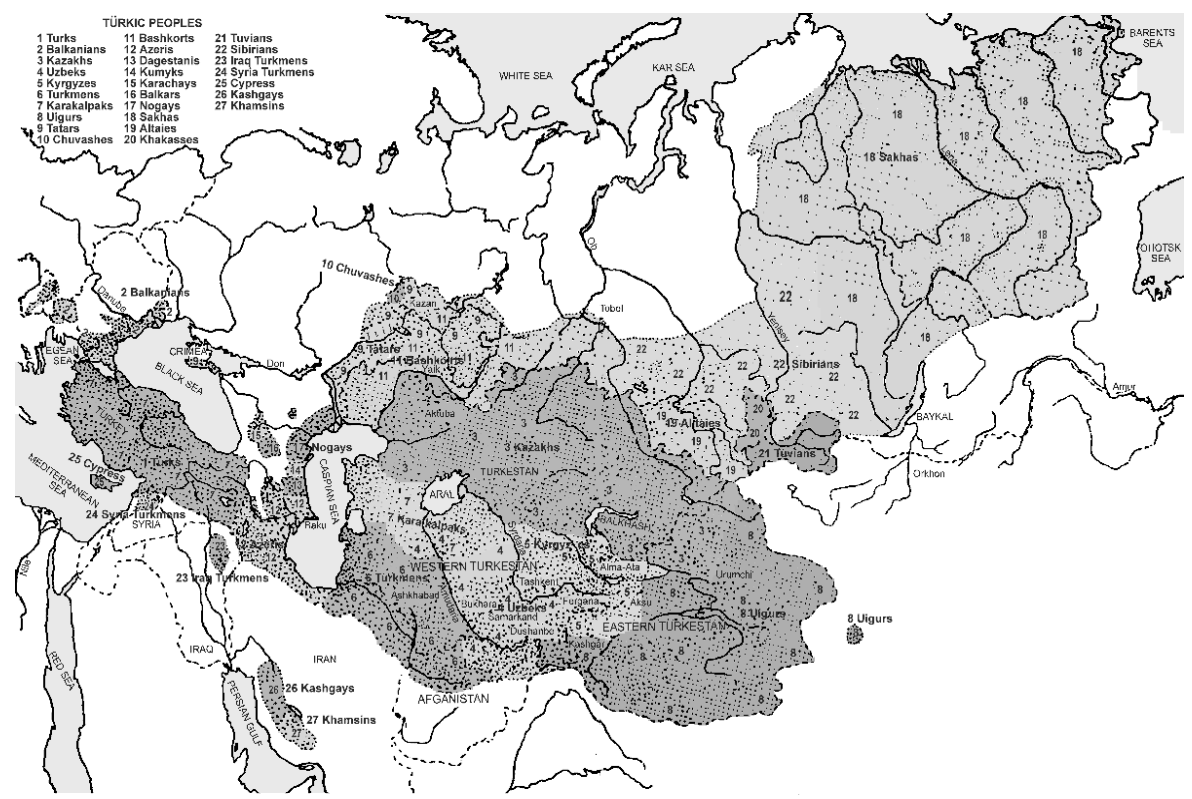

Map 1. Location of the Turkic World (http://s155239215.onlinehome.us/turkic/20Roots/ZakievGenesis/ZakievGe nesis3-18En.htm/)

According to this study, the percentage of those who know the location, capital city and flag of even Azerbaijan, one of the most well-known, is 50\%. The rate is higher among students studying in faculties of Social Studies compared to those in Natural Sciences. A study to identify topics about the Turkic World in the Secondary School Social Studies Curriculum analyzed how social studies courses in the $4^{\text {th }}, 5^{\text {th }}, 6^{\text {th }}$ and $7^{\text {th }}$ classes addressed the topic Turkic World under the curriculum program introduced in 2005. According to the results suggested by the study, the Turkic World was mentioned within 7 topics, however it was not addressed under a separate title (Gülüm and Demirok, 2016). This increases the importance of competence in the Turkic World of the teachers of social studies. Also, it is important that teachers or lecturers critically analyze their lessons and pay an effort in making them better (Rossouw, 2009). In this sense, this study presents a sample as it emerged from an analysis of a university course. 
Images that one creates in his mind about certain topics differ from reality. In the formation of those, one's own attainments are effective. Geographers have defined the images that one creates in his/her own mind which differ from reality as the mental map (Tümertekin and Özgüç, 2009). And our mental maps are formed based on our perceptions (Arnon and Reichel, 2007; Asikhia, 2010; Bunting and Guelke, 1979; Mitchell and Forer, 2010; Weeden, 2007). In a study to measure the perceptions of prospective teachers of social studies about regions and countries, Europe, Middle East and Turkey's neighbors were considered, and identifying the sources which form student perceptions was attempted. It happens that media organizations and books are more prominent than courses in terms of getting information about other countries. This can prevent students from getting the correct information and can form perceptions based on prejudices (Y1lmaz and Yiğit, 2010). Studies reveal systematic information and teachers have substantial influence in forming perspectives on countries (Zevin and Corbin, 1998).

When students were asked to draw a map of Turkic World, the images they have about Turkic World is found rather inexact (Tunçel, 2002). The number of countries they knew were found very few and their knowledge was found to be affected by the agenda. In another study, $6^{\text {th }}$ grade social studies program was found incomplete as the objective about recognizing Turkic World was not met in the program (Çoban and Temir, 2017). Thus, future international relationships were mentioned to be at risk as the related knowledge of $6^{\text {th }}$ graders were insufficient. The content about Turkic World in middle school was also investigated and found insufficient (Bayram, 2011). $7^{\text {th }}$ graders expressed that they learn Turkic World from coursebooks, not history books (Karaçal1, 2012). Also, the number of countries they knew were 2 or less than 2 . When the attitudes were investigated rather than knowledge, different results were found. $7^{\text {th }}$ graders' opinions and feelings about Turkic World were investigated, and it was found that they had positive attitudes towards other Turkic countries and believed Turkic countries are parts of a big whole (Ulusoy, 2009). They felt that Turkic countries' cultures were alike each other, and the cooperation among them should be increased.

Preservice social studies teachers' knowledge of Turkic World was found missing in Çelik's study (2014). When preservice teachers were interviewed, they related Central Asian Turkish history with Pre-Islamic Turkish history and neglected Turkic countries founded after the acceptance 
of Islam. They expressed that they would not prefer to take courses about Turkic World history as they are full of details and difficult to learn. Similarly, a more recent study signals the little knowledge of university teachers from the faculties of education, arts and sciences, engineering, economics and administrative sciences, communication and fine arts about Turkic World (Topal and Sezer, 2016). However, students of geography department were found to have enough information about Turkic World (Alım, 2009). In parallel with this study, the knowledge of university students about Turkic World was found as sufficient (Gülüm and Seyfulayeva, 2013). However, the sample of the study was asked questions only about the personality of Turks. In another study, it was found that future social studies teachers shaped their opinions about Turkic countries on the basis of their political views and history knowledge (Yılmaz and Yiğit, 2010). They categorized Turkic countries as "friend" or "enemy" and regarded "enemy" countries as danger regardless of their development levels. When Turkish preservice teachers were asked about Turkic World, it was found that their information was low, additionally, they expressed that they had little knowledge and not content with this (Taşkaya, 2014). Also, they mentioned the lack of uniformity of Turkic countries as the biggest problem.

\section{Aim of the Study}

This study aims to determine prospective social studies teachers' expectations of Geography of the Turkic World course and understand the impact of this course on changing students' perceptions and knowledge about the Turkic World.

\section{Problem Status}

In what ways has the course on Geography of the Turkic World affected students' perceptions and knowledge about the Turkic World?

\section{Sub problems}

- What are the expectations of students who chose the Geography of the Turkic World course?

- Has the Geography of the Turkic World course created a significant difference in students' knowledge on the Turkic World?

- Has the Geography of the Turkic World course created a significant difference in students' attitudes towards the Turkic World? 


\section{Methodology}

This study was planned as a concurrent/parallel mixed design study. Mixed design studies allow researchers to both analyse a problem quantitatively in numbers and generalize the results, and understand the problem in depth and do not miss the details (Creswell and Clark, 2017). At quantitative level, quasi-experimental research design was implemented. This study is classified under quasi-experimental since it was designed in a single group rather than in separate experimental and control groups (Creswell, 2007). The quantitative level was formed in pre-test and post-test design, while the qualitative level made use of open ended questions and interviews.

\section{Population and Sampling}

The Turkic World course was selected by 17 prospective teachers of social studies in total ( 9 female and 8 male). The sampling of the study is classified as typical case sampling. To understand the phenomenon of Turkic World course, it was required that the participants would take the course. Thus, typical case sampling was selected to describe the course better (Patton, 2002). These 17 prospective teachers of social studies participated in the quantitative stage of the study which was composed of pre-test and post-test. All participants also answered the open-ended questions on the structured form in the qualitative stage.

\section{Context of the Study}

The Turkic World course is an elective course in the social studies bachelor's program at the university where the study was conducted. In the elective course which consisted of a 16-week schedule, lectures took place for 13 weeks since an exam calendar of 2 mid-terms ( 1 presentation) and one final examination was in place at the university. Students were assigned subjects of their interest to research on, and were asked to share their research with their professors and fellow students. The Geography of the Turkic World course has 2 lecture hours per week and 2 credits. Course content covered all communities of Turkic origin including independent states, autonomous republics, autonomous regions or communities in the field that extends from Balkan Peninsula to Pacific shores in the East, and from Arctic Ocean in the North to Tibet in the South. Topics also include, through researches done by students, European countries (particularly Germany) where a significant number of Turkic communities live. Azerbaijan, Turkmenistan, Uzbekistan, Kazakhstan, Kyrgyzstan, Tajikistan, Turkish Republic of Northern Cyprus 
and Turkey are major independent countries in this geography. Many other countries, primarily the Russian Federation, were discussed as course topics where autonomous states or autonomous regions exist. In short, the past and present of all places where Turks and the Turkic culture continue their existence, as well as their relations with Turkey were covered. All students who took the course completed the 16-week period and ended the semester...

In the first day of the course, a pre-test composed of 25 items was conducted to determine why students chose this course and what their expectations, prior knowledge and attitudes were, and 3 open ended questions were asked. At the end of the semester students were asked open ended interpretive questions such as "How did this course change your perspective on the Turkic World and Geography" and the same scale was used as posttest.

\section{Data Collection}

Both qualitative and quantitative data collection tools were designed by the researchers. The pre and post-test used in the study was designed by the researchers reviewing the literature -increasing validity of the tool-, and received expert opinions and tested for reliability and validity. The reliability of the pre-test and post-test was found as $\mathrm{r}=.89$. The pre-test was implemented at the beginning of the semester to understand students' opinions before the course effect. The post-test, on the other hand, was implemented in the last lesson before the final test. The pre-test and post-test were filled by the students themselves while the researchers were in the classroom to answer their possible questions. The qualitative data, on the other hand, was collected from the students at the same time of the pre and post-tests were implemented. Students answered open-ended questions in details and asked their questions to the researchers.

\section{Data Analysis}

The pre-test and post-test data composing the quantitative dimension of the study was analysed using paired sample $t$ test analysis on the SPSS 22 program. The data collected in the qualitative stage of the study was analysed using content analysis where transcription, coding and thematic analysis steps were implemented.

Pre-test-post-test was conducted to test the differences that occurred in the knowledge and attitudes of students who selected the Geography of the 
Turkic World course. The mean difference between pre-test and post-test conducted respectively before and after the term should be compared (Büyüköztürk, 2013) to answer the question "Has a significant change occurred in the knowledge and attitude regarding the Turkic World, of students who took the Geography of the Turkic World course?". It was observed, upon conducting a normality test from $\mathrm{T}$ test analysis assumptions, that the kurtosis and skewness values of students who attended the Geography of the Turkic World course and who took both tests were between -1 and +1 for pre-test and post-test, that the Shapiro-Wilk normality test significance has a value higher than $0.05\left(p_{\text {pre-test }}=.290, p_{\text {post-test }}=.246\right)$, and that q-q plot curves were above normality. These three points indicate that normality assumptions were confirmed (Büyüköztürk, 2013). According to Field (2013), the $t$ test can be used for groups under 30 members that fulfill the normality assumption. Based on this, a paired sample $t$ test was conducted to see the pre-test-posttest difference in the knowledge and attitudes of 17 students who attended the Geography of the Turkic World course. Results were submitted separately for knowledge and attitudes.

\section{Findings}

\section{Difference in the Knowledge and Attitude of Students}

Table 1. Knowledge and Attitude of Students

\begin{tabular}{|c|c|c|c|c|c|c|c|c|c|}
\hline & & \multicolumn{5}{|c|}{$\begin{array}{l}\text { Paired Differences } \\
\end{array}$} & \multirow[t]{2}{*}{$t$} & \multirow[t]{2}{*}{ df } & \multirow[t]{3}{*}{$p$} \\
\hline & & \multirow[t]{2}{*}{ Mean } & \multirow[t]{2}{*}{$\begin{array}{c}\text { Std. } \\
\text { Deviation }\end{array}$} & \multirow[t]{2}{*}{$\begin{array}{c}\text { Std. } \\
\text { Error } \\
\text { Mean } \\
\end{array}$} & \multicolumn{2}{|c|}{$\begin{array}{c}95 \% \text { Confidence } \\
\text { Interval of the Difference }\end{array}$} & & & \\
\hline & & & & & Lower & Upper & & & \\
\hline 总 & 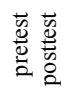 & -5.23077 & 6.5720 & 1.8227 & -9.20224 & -1.25930 & -2.870 & 12 & $.014 *$ \\
\hline $\begin{array}{l}\frac{0}{0} \\
\frac{0}{0} \\
\frac{0}{0} \\
\vdots \\
\vdots\end{array}$ & 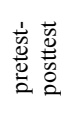 & .81250 & 5.2563 & 1.3140 & -1.98841 & 3.61341 & .618 & 15 & .546 \\
\hline
\end{tabular}

The paired sample $t$ test results are given on Table 1. The results show a significant difference at the attitude level $(p=.014<.05)$. In other words, it can be stated that a statistically significant change has occurred in the attitude towards the Turkic World of students who selected the Geography of the Turkic World, and that the course has positively affected the students. On the other hand, the Geography of the Turkic World course did not cause a statistically significant difference in students' knowledge $(p=.546>.05)$. 


\section{Course Expectations of Students}

At the beginning of the course, 4 open-ended questions were asked to the students. Questions under the following headlines were asked and answers were collected respectively: why they chose the course, what was their expectations from the course, of what the phrase Turkic World reminds, and how they would define the Turkic World.

Table 2. Reasons for Choosing the Geography of the Turkic World Course

\begin{tabular}{lcc}
\hline Theme & $\mathbf{F}^{*}$ & $\mathbf{\%}$ \\
\hline Interest in the Turkic World- Understanding the term "Turkic World" & 7 & 31.8 \\
Trust in the professor & 5 & 22.7 \\
Because it is a geography course & 5 & 22.7 \\
The most appealing elective & 5 & 22.7 \\
\hline Total & 22 & 100 \\
\hline
\end{tabular}

*Students gave multiple answers.

The question "Why did you choose the Geography of the Turkic World course?" aims to discover the reasons why the students chose the course that was offered as an elective. The findings were given on Table 2 . The two most frequent answers from the students to this question were that they were interested in the Turkic World, and that they wanted to understand the term "Turkic World". Along with those, the answers stating the trust in the professor teaching the course, the fact that it was a geography course, and that it was the most appealing course among the electives were also among the reasons. As a reason for choosing the course, student 10 stated "freeing from prejudices and getting correct information" while student 17 replied "I chose this course to better understand the origins of my society and its cultural characteristics.". Student 9 said "This course was the only geography course among the electives that is why I chose it.". Student 15 explained her preference as follows: "I chose this course because I knew I would learn something from the professor teaching it." Based on these answers, it can be said that the reasons for which students chose the course show a balanced distribution and various reasons played roles in why the Geography of the Turkic World course was chosen. 
Table 3. Expectations of Students from the Geography of the Turkic World Course

\begin{tabular}{|c|c|c|}
\hline Theme & $F^{*}$ & $\%$ \\
\hline $\begin{array}{l}\text { Getting sufficient information about the Turkic World Culture- } \\
\text { Geography-History-Language }\end{array}$ & 15 & 71.4 \\
\hline Active teaching & 3 & 14.2 \\
\hline Objective teaching & 2 & 9.2 \\
\hline Entertaining nature of the course & 1 & 4.1 \\
\hline Total & 21 & 100 \\
\hline
\end{tabular}

*Students gave multiple answers

The question "What are your expectations from the Geography of the Turkic World course?", which was asked to determine student expectations, brought to light what students expected from the course in terms of content and methodology. The findings were given on Table 3. The most frequent answer, "getting sufficient information", reveals student expectations about course content. In addition, active teaching, objective teaching and entertaining nature of the course reveal student expectations about course format. It was also detected that although students studied in social studies education, their awareness about the Turkic World was not high and the need to make up for this deficiency was effective on their course selection. Student 8 stated their expectation of the course as "to grasp the meaning of the Turkic World concept, to compare the values, history, geography and culture of the Turkic World with our own culture and to discover common grounds".

Table 4. Turkic World in Student Perceptions

\begin{tabular}{lcc}
\hline Theme & $\mathrm{F}^{*}$ & $\%$ \\
\hline Central Asia & 10 & 50 \\
Turkey - Anatolia & 5 & 25 \\
Turkish speaking territories & 3 & 15 \\
Sadness - Pain & 2 & 10 \\
\hline Total & 20 & 100 \\
\hline
\end{tabular}

*Students gave multiple answers

Notions that the students associated the Turkic World with are presented in Table 4, which contains the 4 most frequent answers of the students. Student 7 expressed their opinion as "Before I attended this course, I thought Turks were a nation who has lived in Central Asia only; but now I have learned that they have expanded to different parts of the world.". The "Turkey-Anatolia" answer, which came up frequently in interviews, was 
recorded as the second most frequent answer in both the pre-test and the posttest this finding is pointed out by student 3 as follows: "The center of the Turkic World is Anatolia, in other words the Republic of Turkey, because it is the only state that can protect and lead the Turkic World.".

Table 5. How Students Defined the Turkic World

\begin{tabular}{lcc}
\hline Theme & $\mathrm{F}^{*}$ & $\%$ \\
\hline Countries in Central Asia & 8 & 34.7 \\
Nonunified & 5 & 21.7 \\
Rich in mineral resources & 3 & 13.04 \\
Right geographical definition & 2 & 8.6 \\
Receiving no support from Turkey & 2 & 8.6 \\
Having a bright future & 1 & 4.3 \\
Of Turkic ethnicity & 1 & 4.3 \\
Identifying themselves with the Turkic Culture & 1 & 4.3 \\
\hline Total & 23 & 100 \\
\hline
\end{tabular}

*Students gave multiple answers.

In this part which aims to determine the students' definitions of the Turkic World, various answers were received regarding the geographical features, political state and culture of the Turkic World. These answers, which indicate that the students were capable of versatile thinking on the Turkic World, are ranked in the table according to frequency and their frequency values are given (Table 5).

\section{Effects of the Course on the Geography of the Turkic World}

In this section, participants were asked to assess the course through open-ended questions, and findings were given in order of frequency with frequency values and percentages (Table 6).

At the end of interview, the most frequent theme which was obtained was the theme "relations". Students expressed their discontent with the relations among countries belonging the Turkic World as follows: "Relations among these states are very weak" (Student 3), "Turkey should have stronger relations with Turkistan. After all, it is also part of the Turkic World." (Student 2 ), and "Even the trade relations are as little as almost none" (Student 1). Furthermore, it was revealed that the students showed deeper interest in "Turks abroad" and mention them frequently. "Turks abroad" is the second most frequent theme encountered in this study. Under this theme, it was observed that the students' understanding of Turkness has expanded and 
Turks of which nation/geography they include in their definition of Turks abroad.

Table 6. Learning Outcomes Assessment of the Geography of the Turkic World Course

\begin{tabular}{|c|c|c|c|}
\hline Main Theme & Sub-themes & $F^{*}$ & $\%$ \\
\hline \multirow{6}{*}{ Relations } & Internal relations within the Turkic World are weak & 15 & 44.1 \\
\hline & Relations with Turkey are weak, should be strengthened & 14 & 41.1 \\
\hline & Turkey and Azerbaijan are the only ones with strong relations & 2 & 5.4 \\
\hline & Trade is low & 2 & 5.4 \\
\hline & Not identifying themselves as Turks & 1 & 2.9 \\
\hline & Total & 34 & 100 \\
\hline \multirow{7}{*}{ Turks Abroad } & Turkistan (mentioned as Central Asia) & 7 & 24.1 \\
\hline & Balkans & 7 & 24.1 \\
\hline & Autonomous Republics & 7 & 24.1 \\
\hline & Western Thrace & 4 & 13.7 \\
\hline & Turks in Europe & 2 & 6.8 \\
\hline & Turks in Middle East & 2 & 6.8 \\
\hline & Total & 29 & 100 \\
\hline \multirow{4}{*}{$\begin{array}{l}\text { From errors } \\
\text { to truth, from } \\
\text { superficial to } \\
\text { in-depth } \\
\text { knowledge }\end{array}$} & $\begin{array}{l}\text { Turks live in a very large geography } \\
\text { (Do not consider only Central Asia, or only Turkey and Caucuses) }\end{array}$ & 15 & 57.6 \\
\hline & $\begin{array}{l}\text { At first seeing them as nomads but afterwards understanding that they } \\
\text { are a great civilization, }\end{array}$ & 8 & 30.7 \\
\hline & Starting to use the term Turkistan & 3 & 11.5 \\
\hline & Total & 26 & 100 \\
\hline \multirow{5}{*}{$\begin{array}{l}\text { Unpleasant } \\
\text { Events in the } \\
\text { Past and } \\
\text { Present }\end{array}$} & Deportation, deaths and assimilation in the Soviet era & 12 & 46.1 \\
\hline & Practices of China on Eastern Turkistan & 7 & 26.9 \\
\hline & Practices of Russia on Turks within its boundaries & 4 & 15.3 \\
\hline & Karabag issue of Azerbaijan and incidents of Xocali & 3 & 11.5 \\
\hline & Total & 26 & 100 \\
\hline \multirow{4}{*}{ Benefits } & Increase in interest and curiosity & 14 & 73.6 \\
\hline & Embracing attitude & 3 & 15.7 \\
\hline & Necessity of the course being taken by all departments & 2 & 10.5 \\
\hline & Total & 19 & 100 \\
\hline \multirow{3}{*}{$\begin{array}{l}\text { Realization of } \\
\text { common and } \\
\text { different } \\
\text { features } \\
\end{array}$} & Cultural & 11 & 78.5 \\
\hline & Religious/Sectarian & 3 & 21.4 \\
\hline & Total & 14 & 100 \\
\hline
\end{tabular}

Findings from the frequency assessment indicates that the students placed Turkistan, Balkans, Autonomous Republics, Western Thrace, Turks in Europe and Turks in the Middle East under the concept of "Turks Abroad" Students expressed their interest in the Turks Abroad with the following words: "I have realized the great suffering that Eastern Turkistan is currently grappling with." (Student 4), "I have learned about the term Western Thrace in this course for the first time. I saw what the remaining Turks go through there." (Student 5), and "I thought there were only Muslims in the Balkans. I 
found out that there are also Turks there." (Student 1). In addition, Student 11 said "I was deeply touched by the pain the Bosnians experienced in 1990s." while Student 5 pointed out "Srebrenica Massacre is a deep unforgettable sorrow for the Turkic World.". Student 2 shared his/her thoughts "I also immigrated from Bulgaria. This course has enabled me to better understand the troubles my ancestors went through before coming here. Balkans are now more precious to me with respect to the Turkic World."

Under the headline "From errors to truth, from superficial to in-depth knowledge" which came up as the third most frequent theme, it was concluded that the students understood how large the Turkic World geographically is and what a great civilization it is, and that they started to use the name Turkistan for the first time. Student 5 said "I used to think of the Turkic World as a much narrow area. Now I know that it extended in such large territories." whereas Student 2 stated "I have started to use the name Turkistan.". Another theme emerging in the same frequency as the theme "From errors to truth, from superficial to in-depth knowledge" was "Unpleasant Events in the Past and the Present". It was observed that the students realized the past and current unpleasant events related to the Turkic World with this course. Student 11 pointed out the hardships experienced by Turks in the Soviet era as follows: "What in the Soviet era happened, for example... People were slaughtered, assimilated. We had no idea about these.", student 13 on the other hand, noticing another issue, stated: "Recently a lot has happened in China. Our fellow people from Eastern Turkistan suffered a great deal there.". Similarly, student 11 stated "I learned how Karabag issue was important and felt the pain of what happened in Xocali. I believe it is a genocide."

Under the main theme "Benefits", the sub-themes increase in interest and curiosity, embracing attitude, and necessity for the course to be offered by all departments were obtained. Student 8 expressed an increase in interest compared to before by stating "My interest in the Turkic World has increased through this course.", while student 7 pointed out the impact of the course on developing an embracing attitude as follows: "Through this course, I started to identify myself more with the Turkic World, I came to embrace it more." and "Realization of common and different aspects." which was discussed as the last theme, indicates that the students saw the differences and similarities among the Turkic World states. Student 15 drew attention to the similarity among states in the Turkic World by saying "Through this course I realized 
the states in the Turkic World are very similar. We have a lot in common especially in cultural terms.", whereas student 12 said they saw the differences: "I had presumed that all Turks belonged to the same religion and sect. It turns out, however, there were those belonging to different religions."

\section{Discussion and Conclusion}

The purpose of this study was to reveal the effect of the course on the Geography of the Turkic World, on prospective teachers of social studies, with respect to the Turkic World and Turkic culture. As noted in findings, significant differences have been observed in the way prospective social studies teachers looked at topics and concepts and in their knowledge level after they attended a course on the Turkic World. This is also the case in the study by Topal and Sezer (2016) titled "Determining the awareness level of university students about the geography of the Turkic world". Data was collected from 800 university students in total, 258 of which were from education faculties.

Another finding of the study is that participants were asked to define the Turkic World at the beginning of the semester and could not present a clear definition. This shows similarities with the study Alim (2009) conducted on geography education students, where the researcher stated that there were differences among students in terms of both defining the Turkic World and clearly setting its boundaries. A similar conclusion is true for this study.

To elaborate, it was concluded that the mental map formed in the minds of the students has changed through the Turkic World course. Students, who thought, before taking the course, of the Turkic World as Central Asia or Balkans, argued that such perceptions changed through the course. This finding revealed by the qualitative data was confirmed also with the pre-test and the post-test. Indeed, in the pre-test the students had associated the Turkic World with a clearer geographical area, whereas this clarity was observed to be lower in the post-test and they no longer considered the Turkic World limited to only Central Asia, Balkans or Anatolia. Mental maps of students about Turkic countries has also been found faulty in the study done with a sample size of 400 students (Tunçel, 2002). Also in Tunçel's study, school education has been found effective in formation Turkic countries mental maps.

Furthermore, it is seen that the qualitative and quantitative data support each other. Under the theme "relations", most frequently encountered theme 
in student assessments, the students spoke of weak relations between countries in the Turkic World, and this is in parallel with the literature. Most of the studies about the opinions regarding Turkic World signal discontent with the relationships among Turkic countries (Çoban and Temir, 2017; Taşkaya, 2014; Ulusoy, 2009). Negative views of students where they reported in the post-test and pre-test regarding Turkey's support for the Turkic World are seen here, as well. In this sense, it could be stated that these two sets of data verify each other. The students highly agreed to the 7th item of the questionnaire "The Turkic World and Turkey are integral parts of a whole." both in the pre-test and the post-test (47\% pre-test, $87.2 \%$ post-test) and asserted the importance of the relationship between Turkey and the Turkic World. This finding is in parallel with Ulusoy's (2009) study where $7^{\text {th }}$ grade students expressed the wholeness of Turkic worlds. On the other hand, the students highly agreed to the item "Turkey fails to show the necessary interest in the Turkic World" both in the pre-test and the post-test $(50 \%$ pre-test, $48.8 \%$ post-test), where the students indicated their discontent with relations. Thus, integrity in study was reached and data verification was conducted.

We encounter another example in students' definition of the Turkic World. Pre-test and post-test findings resulting in that the Turkic World is mostly associated with Central Asia ( $88.6 \%$ pre-test, $69.4 \%$ post-test) and the fact that students refer to Central Asia countries in their definition of Turkic World are consistent with each other. Additionally, students spoke of low support from Turkey when defining the Turkic World (8.6\%), while as part of the quantitative data, they showed discontent with Turkey's attitude in relation to the Turkic World in the pre-test (58.8\%) and supported the same opinion in the post-test (47.2\%). Furthermore, responses given to the item "Turkey does not show the necessary interest in the Turkic World" in the quantitative scale indicate that $58.8 \%$ (post-test result) of students agree with this statement. Results of another item addressing the relations between Turkey and the Turkic World (Item 8-"Turkey is too inactive about the Turkic World.") suggest that the students found Turkey's efforts inadequate (64.7\%). The consistency between the qualitative and quantitative data indicates that students are concerned about Turkey's support to the Turkic World (Table 4). Students' perception of Turkey's role in Turkic world is also noticeable in Bayraktaroğlu and Mustafayeva's (2010) study. They express Turkey be more active in unifying Turkic countries. 
Similarly, we find an increase in interest and curiosity, both in qualitative and quantitative data. The participants stated that their interest in and curiosity about the Turkic World increased through the Turkic World course. This result obtained in interviews is also supported by quantitative data. Students taking the course draw a higher graphic in the post-test in terms of watching documentaries about the Turkic World (23.5\% pre-test, $41.2 \%$ post-test). However, the attitude of the students towards watching documentaries about the Turkic Worlds did not display the same pattern in following news about the Turkic World. Indeed, pre-test results show that students were more interested in news about the Turkic World (67.4\%) whereas post-test results show that they were less interested in news (46.3\%). Similar to the study where authentic experience increased student engagement (Koen and Ebrahim, 2013), this study revealed real-world content increased student curiosity and interest.

In addition to the fact that the qualitative and quantitative data support one another, a more in-depth analysis was achieved through qualitative data, and information which could not be acquired through quantitative data could be obtained. An example is that course assessments enabled collecting data which could not be collected through the questionnaire. "The common and different aspects" noticed by the students, in particular, show that they reached also a different kind of information about the Turkic World. Those conveyed by the students under this item indicate that they can also see the common and different aspects about the culture, religion and sect of the Turkic World. Likewise, the fourth theme of the study "Unpleasant events in the past and the present" revealed that students acquired information, which was not in the questionnaire. Especially the deportations, deaths of innocent and assimilation in the Soviet Socialist Republic, practices of China on Eastern Turkistan, Karabakh issue, and practices of Russia on Turks that lived in its boundaries were identified as events that caught the students' attention. Different from the literature this finding is a contribution to the field.

In a similar way, image the Turkic World created in the participants' minds were also described in the interviews as "Turkish speaking territories" and "sadness and pain". The oppression and atrocities suffered to date by Turkic communities in different parts of the world, being discussed in class with video and photograph support, played a role in the Turkic World to be perceived as a geography of sadness and pain. Especially the suffering of 
Uyghur Turks in Eastern Turkistan and of Turkic population in the Balkans, what happened in Xocali in 1992, Balkan Turks that were forced to migration due to oppression, difficulties that Meskhetian Turks and Crimean Turks went through may have raised such awareness in students? Student 1 has stated: "I had always seen the troubles facing other nations in the media or elsewhere; then for the first time I witnessed the suffering of my own.". Student 4 mentioned their new mental state as follows: "I had thought Eastern Turkistan was exploited for the sake of simple nationalism and had ignored the issue, until I attended this course.". Student 9 made a general comment by saying "I would never want any nation on Earth, not just Turks, to face such sorrow and pain. Especially the incidents in Xocali makes me feel sorrow each time I remember.".

To sum up, the findings of this study is similar with the literature in terms of low knowledge level of students about Turkic world (Bayram, 2011; Topal and Sezer, 2016; Tunçel, 2002). Also, this study is in parallel with other studies in terms of the wholeness of Turkic world (Ulusoy, 2009) and Turkey's key role in unifying these countries (Çoban and Temir, 2017).

\section{Implications}

The data revealed that the knowledge of university students about the Turkic World is extremely insufficient and superficial, which is a similar conclusion with other studies (e.g. Alım, 2009; Topbaş and Baran 2010; Topal and Sezer 2016). Considering in particular, the existence of studies which express the situation to be more problematic among the students of natural sciences, it is necessary to underline the importance of including courses on the Geography of the Turkic World, among the elective courses on social studies, in the scope of social studies elective practices at universities. Education Faculty students, as teachers of the future, constitute the primary group who require more attention compared to students of other faculties. This course, which is in the elective courses catalogue of Education Faculties Curriculum, must primarily become a compulsory course in Social Studies, History, Geography and Turkish Language departments, and must be taught as an elective in other departments. Also, the content of social studies course in middle school should be revised to include more information about Turkic world. 


\section{References}

Alım, M. (2009). Coğrafya eğitimi öğrencilerinin Türk dünyası algıları (Atatürk Üniversitesi Örneği). Uluslararası İnsan Bilimleri Dergisi, 6(2), 574-586.

Arnon, S. and Reichel, N. (2007). Who is the ideal teacher? Am I? Similarity and difference in perception of students of education regarding the qualities of a good teacher and of their own qualities as teachers. Teachers and Teaching: Theory and practice, 13(5), 441-464.

Asikhia, O. A. (2010). Students and teachers' perception of the causes of poor academic performance in ogun state secondary schools. European Journal of Social Sciences, 13(2), 229-242.

Atasoy, E. and Soykan, A. (2008). Saha (Yakut) Cumhuriyeti: Coğrafi kimlik analizi denemesi. Muğla Üniversitesi Sosyal Bilimler Enstitüsü Dergisi (ILLKE), Autumn, 21, 33-60.

Bayraktaroğlu, S. and Mustafayeva, L. (2010). Türk yüksek öğretim sistemi ve Türk dünyası ilişkileri: Sakarya üniversitesinde eğitim gören yabancı uyruklu öğrenciler orneği. Journal of Azerbeijani Studies, 12(1-2), 284-292.

Bayram, B. (2011). Sosyal Bilgiler Öğretiminde Türk Dünyası. Unpublished master's thesis, Niğde Üniversitesi Sosyal Bilimler Enstitüsü.

Bunting, T. E. and Guelke L. (1979). Behavioral and perception geography. A critical appraisal. Annals of the Association of American Geographers, 69(3), 448462.

Büyüköztürk, Ş. (2013). Sosyal bilimler için veri analizi el kitabı: istatistik, araştırma deseni, SPSS uygulamaları. Ankara: Pegem Yayıncılık.

Çelik, H. (2014, June). Orta Asya Türk tarihinin öğretimine ilişkin sosyal bilgiler öğretmen adaylarının görüşleri: Sakarya üniversitesi örneği. In A. Şimşek, S. Kaymakçı and İ. Turan, (Eds.), 3. Uluslararası Tarih Eğitimi Sempozyumu tam metin kitapçı̆̆ (pp.25-27).

Çoban, A. and Temir, M. (2017). Sosyal bilgiler müfredatında Türk dünyası konusu ve dış politikamıza etkilerine ilişkin akademisyen görüşleri. Sosyal Bilimler Dergisi, 18(4), 105-115.

Creswell, J. W. and Clark, V. L. P. (2017). Designing and conducting mixed methods research. Sage publications.

Creswell, J. W. (2007). Qualitative inquiry and research design: Choosing among five approaches $\left(2^{\text {nd }}\right.$ ed.). Thousand Oaks, CA: Sage.

Doğanay, H. (1995). Türk dünyasının siyasi sınırları. Doğu Coğrafya Dergisi, 1(1), $132-154$.

Field, A. (2013). Discovering statistics using IBM SPSS statistics. London: SAGE.

Gülüm, K. and Demirok, U. (2016). Sosyal bilgiler müfredat programlarında Türk dünyası ile ilgili konuların analizi. Dumlupınar Üniversitesi Sosyal Bilimler Dergisi, Avrasya Özel Sayıs1-Aralık, 318-329.

Gülüm, K. and Seyfullayeva, N. (2013). Üniversite öğrencilerinin Türk dünyası algısı ve bilgi kaynakları. Turan Stratejik Araştırmalar Dergisi, 5(18), 69-79.

Gündoğdu, A. (2009). Türk Jeopolitiği: Akdeniz'e bir kısrak, Hazara bir kartal başı gibi uzanan bu memleket. İstanbul: IQ Kültür Sanat Yayıncılık.

http://s155239215.onlinehome.us/turkic/20Roots/ZakievGenesis/ZakievGene sis3-18En.htm

Kafesoğlu, İ. (2012). Türk milli kültürü. Ankara: Ötüken Neşriyat. 
Kalafat, Y. K. (1994). Günümüz Türk dünyasına genel bakış. Erciyes Üniversitesi Sosyal Bilimler Dergisi, 5, 467-474.

Karaçalı, H. (2012). 7. sınıf ögrencilerinin zihin haritasında türk dünyası algısı. Unpublished master's thesis, Gazi Üniversitesi Eğitim Bilimleri Enstitüsü.

Koen, M. and Ebrahim, H. B. (2013). Using real-worldness and cultural difference to enhance student learning in a Foundation Phase Life Skills module. South African Journal of Education, 33(3), 1-13.

Köklü, N. (1995). Tutumların ölçülmesi ve likert tipi ölçeklerde kullanılan seçenekler. Ankara Üniversitesi Ë̆itim Bilimleri Fakültesi Dergisi, 28(2), 81-93.

Doi: 10.1501/Egifak 0000000299

Lai, K. C. (1999). Freedom to learn: A study of the experiences of secondary school teachers and students in a geography field trip. International Research in Geographical and Environmental Education, 8(3), 239-255.

Mitchell, P. and Forer, P. (2010). Blended learning: The perceptions of first-year geography students. Journal of Geography in Higher Education, 34(1), 77-89.

Özder, A. (2013). Avrasya kavramı ve önemi. Avrasya Incelemeleri Dergisi (AVID), 2(2), 65-88.

Özey, R. (2009). Türk Dünyası Coğrafyası. İstanbul: Aktif Yayınevi.

Rossouw, D. (2009). Educators as action researchers: Some key considerations. South African Journal of Education, 29(1), 1-16.

Sezer, A. (2011). Cumhuriyet dönemi ortaöğretim coğrafya derslerinde Türk dünyası coğrafyasının öğretimi. Türklük Bilimi Araştırmaları (TÜBAR), 29, 341-373.

Taşkaya, M. (2014). Sınıf öğretmeni adaylarının Türk dünyası algısı. Researcher: Social Science Studies, 2(2), 44-55.

Topal, E. and Sezer, A. (2016). Üniversite öğrencilerinin Türk dünyası coğrafyasına ilişkin farkındalık düzeylerinin belirlenmesi. Marmara Coğrafya Dergisi, 33, 96-113.

Topbaş, E. and Baran H. S. (2010). Türk dünyası coğrafyasında yer alan ülkeler arasındaki kültürel ilişkilerin güçlendirilmesinde eğitim kurumlarının rolü, Journal of Azerbaijani Studies, 3, 252-268, http://dspace.khazar.org/jspui/bitstream/123456789/919/1/20.pdf

Tümertekin, E. and Özgüç, N. (2009). Beşeri cŏgrafya: insan kültür mekan. İstanbul: Çantay Kitabevi.

Tunçel, H. (2002). Türk öğrencilerin zihin haritalarinda islam ülkeleri. Fırat University Journal of Social Science, 12(2), 83-103.

Türkkahraman, M. and Fidan, S. (2005). Türk dünyası ve mana etrafinda bütünleşme. Hacettepe Üniversitesi Türkiyat Araştırmalarl, 2, 75-90.

Ulusoy, K. (2009). İlköğretim 7. sinıf öğrencilerinin Türk Dünyası ve Türk Cumhuriyetlerine yönelik tutum ve düşünceleri. Selçuk Üniversitesi Türkiyat Araştırmaları Dergisi, 1(26), 357-377.

Weeden, P. (2007). Students' perceptions of geography: Decision making at age 14. Geography, 92(1), 62-73.

Wood, L. J. (1970). Perception studies in geography. Transactions of the Institute of British Geographers, 50, 129-142

Yiğit, A. (2000). Türk ülkeleri ve Türklerin yaşadıkları bölgelerin coğrafyası. Elazığ: Türkiye ve Türk Dünyası İktisadi ve Sosyal Araştırmalar Vakfı Elazığ Şubesi Yayınları 2. 
Yılmaz, K. and Yiğit, Ö. (2010). Sosyal bilgiler öğretmen adaylarının Avrupa, Ortadoğu ve Türkiye'ye komşu ülkelere ilişkin algıları. Hacettepe Üniversitesi Eğitim Fakültesi Dergisi, 38, 318-334.

Zevin, J. and Corbin, S. S. (1998). Measuring secondary social studies students' perceptions of nations. Social Studies, 89(1), 35-38, http://www.tandfonline.com/doi/pdf/10.1080/00377999809599820 